\title{
Penguatan Pendidikan dan Pengembangan Potensi Perdesaan
}

\author{
Eky Prasetya Pertiwi ${ }^{1)}$ \\ Ianatuz Zahro ${ }^{1)}$ \\ 1) IKIP PGRI Jember
}

Eky.prasetya.pertiwi@gmail.com

\begin{abstract}
ABSTRAK: Kegiatan pengabdian yang dilakukan di desa Mayang adalah berupa pendampingan Kuliah Kerja Nyata/KKN. Pendampingan ini merupakan pendampingan pada mahasiswa KKN IKIP PGRI Jember. Hasil yang didapat adalah terbaginya mahasiswa KKN dengan memfokuskan pada dua hal penguatan yaitu penguatan pendidikan dan penguatan pada sector ekonomi. Upaya penguatan di bidang pendidikan kegiatan yang dilakukan adalah lomba mewarnai pada Anak Usia Dini. Sedangkan pendampingan pada pengembangan potensi yang dilakukan di desa Mayang adalah pendampingan budi daya jamur.

Kata kunci : Pengabdian, Pembedayaan Masyarakat, Penguatan Pendidikan, Penguatan Ekonomi

ABSTRACT: The service activities carried out in the village of Mayang were in the form of mentoring the Community Service Program. This assistance is a mentoring for KKN PGRI Jember students. The results obtained were the sharing of KKN students by focusing on two things, namely strengthening the strengthening of education and strengthening in the economic sector. Efforts to strengthen education in the field of activities carried out are coloring competitions for Early Childhood. While assistance in developing the potential undertaken in the village of Mayang is assisting mushroom cultivation.
\end{abstract}

Keywords: Community Service, Community Development, Strengthening Education, Strengthening Economic.

\section{PENDAHULUAN}

Setiap desa mempunyai potensi yang siap dikembangkan. Potensi tersebut juga bisa dilihat dari dua aspek, diantaranya dari sumber daya alam dan sumber daya manusia. Potensi dari alam atau biasa disebut non fisik bisa dicontohkan tanah, air, cuaca dan ternak serta bisa juga dicontohkan manusia yang berperan sebagai tenaga kerja. Sedangkan potensi non fisik bisa diartikan sebagai adanya aparatur desa yang baik yang menjadi kelancaran jalannya roda pemerintahan, adanya lembaga sosial desa sebagai penampung aspirasi masyarakat desa dan sebagai pendorong partisipasi warga desa dan pendorong kegiatan dalam upaya pembangunan desa. Serta adanya masyarakat desa yang memiliki semangat untuk selalu membangun desa.

Potensi perdesaan yang dilihat dari penguatan sumberdaya manusia dapat dilihat dalam bidang pendidikan. Penguatan pendidikan dalam konteks desa harus beriringan dengan pengambangan perekonomian perdesaan. Karena desa merupakan benteng pertahanan nasional dalam dinamika dan kompetisi global. Penguatan pendidikan pada anak usia dini menjadi pilihan karena anak usia dini merupakan usia yang tepat dimana 
pada usia dini adalah masa yang peka, yaitu masa terjadinya kematangan fungsi fisik dan psikis. Dan pada usia dini merupakan tempat peletakan pendidikan fundamental dalam memberikan kerangka dasar agar terbentuk pengetahuan, sikap dan keterampilan pada anak. Dengan memberikan rangsangan perkembangan yang kuat pada anak usia dini diharapkan kedepannya anak lebih siap menerima apapun yang akan dihadapi pada masamasa perkembangan selanjutnya. Tantangan yang harus dipersiapkan adalah kemajuan globalisasi. Globalitas saat ini telah menjadi keniscayaan dan sangat sulit dihindari. Oleh karena itu, masyarakat desa beserta kalangan stakeholder harus memberikan perhatian dan kerja konkrit untuk itu semua.

Stakeholder yang terlibat dalam upaya penguatan desa adalah mereka yang memiliki upaya adanya perubahan ke arah yang lebih baik. Stakeholder yang dimaksud bisa saja aparat pemerintah, perangkat desa, masyarakat, pelajar, pemerhati desa, mahasiswa, dosen, serta pihak pihak yang mempunyai perhatian pada desaserta mampu memberikan pengaruh yang lebih bak pada desa. kea rah yang Stakeholder tersebut memiliki peran yang diharapkan mampu merubah desa agar desa lebih sejahtera. Kesejahteraan desa bisa dilihat dari tingkat perekonomian desa dan tingkat pendidikan. Untuk itu perlu adanya penguatan dalam kedua bidang tersebut.

Salah satu desa yang menjadi perhatian dalam penguatan desa adalah Desa Mayang. Masyarakat Desa Mayang memiliki potensi dalam hal budi daya jamur. Budi daya jamur di Desa Mayang dimulai Tahun 2018 sempat menerima bantuan dari pemerintah namun kurang mendapat perhatian lebih. Sampai tahun 2018 budi daya jamur belum menunjukkan perkembangan yang bagus. Pada akhirnya pada tahun 2018 ini mahasiswa KKN dari Universitas Jember melakukan budi daya jamur lagi, namun tetap tidak memberikan hasil yang memuaskan. Sehingga pada KKN Mahasiswa IKIP PGRI Jember tahun 2018 berupaya membantu mengobservasi kembali mulai dari tahap awal pembibitan sampai pada tahap akhir.

Pada bidang pendidikan, sarana dan prasarana yang dimiliki masyarakat desa Mayang masih kurang memadai (observasi awal tim KKN Desa Mayang) seperti kurangnya tenaga pendidik di Madrasah Ibtida'iyah Nurul Jadid sehingga berdampak pada kurangnya minat belajar siswa Madrasah Ibtida'iyah Nurul Jadid. Selain itu pembelajaran yang kurang terencana di TK Al-Husni menunjukkan bahwa masih perlunya suatu upaya untuk meningkatkan kualitas pengajaran di TK tersebut. Pada kegiatan pengabdian ini, akan difokuskan pada dua masalah diantaranya, pada perihal budi daya jamur sebagai upaya pengembangan potensi desa bidang perekonomian dan yang kedua pada perihal penguatan pendidikan terkait upaya merangsang potensi anak usia dini di desa Mayang. Stakeholder yang terlibat dalam kegiatan ini adalah dosen serta tim KKN IKIP PGRI Jember 2018. Berdasarkan latar belakang tersebut maka rumusan masalah yang akan di bahas adalah: Bagaimana pendampingan KKN yang dilakukan dalam upaya penguatan di bidang pendidikan serta pengembangan potensi yang dilakukan di desa Mayang? 
Tujuan Pengabdian Masyarakat

1. Membantu memberikan pendampingan dalam upayan penguatan dibidang pendidikan pada anak usia dini di desa Mayang

2. Membantu memberikan kegiatan pendampingan dalam mengembangkan potensi desa Mayang dalam hal budi daya jamur.

\section{METODE PELAKSANAAN}

\section{Tempat dan Waktu}

Kegiatan pengadian masyarakat ini bertempat di Desa Mayang Kecamatan Mayang Kabupaten Jember. Waktu pelaksanaan kegiatan KKN-PPM berlangsung sejak 21 Februari 2018 sampai 25 April 2018, selama kurang lebih dua bulan dengan melakukan rangkaian kegiatan dan pendekatan pada masyarakat. Pada kegiatan pendampingan yang dilakukan dosen pembimbing lapangan, pendampingan dilakukan dengan betatap muka langsung serta membuat strategi bersama mahasiswa agar program yang dijalankan berjalan lancer.

\section{Khalayak Sasaran}

Khalayak sasaran pengabdian masyarakat adalah masyarakat desa Mayang Kabupaten Jember. Khalayak sasaran diutamakan adalah masyarakat yang memiliki potensi namun belum bisa mengembangkan potensi nya karena adanya kendala. Yaitu petani jamur. Sedangkan penguatan dalam di bidang pendidikan khalayak sasaran adalah anak usia dini.

\section{Jenis Kegiatan}

Potensi desa Mayang yang akan dikembangkan meliputi dua hal, diantaranya: (1) upaya mengembangkan budi daya jamur tiram, dan (2) penguatan pendidikan yakni dengan mengembangkan potensi anak usia dini melalui lomba mewarnai. Jenis Kegitan Pengabdian ini berupa Kuliah Kerja Nyata yang melibatkan mahasiswa, masyarakat dan dosen pebimbing lapangan.

\section{Metode yang digunakan dalam pendampingan KKN}

Dalam kegiatan pengabdian masyarakat ini, dosen bertugas memberikan pendampingan pada mahasiswa KKN. Pendampingan yang dilakukan adalah berupa:

1. Memberikan pendampingan pada mahasiswa dalam hal persiapan dan perencanaan, pelaksanaan, pemantauan terhadap kegiatan program kerja KKN 
2. Memberikan pendampingan dalam hal pelaksanaan program kegiatan desa mulai dari melakukan pendekatan terhadap masyarakat serta ketika event desa dilaksanakan

3. Melakukan pengorganisasian dengan mahasiswa KKN agar kegiatan berjalan dengan baik dan maksimal

4. Melakukan pendampingan dengan mengevaluasi kegiatan secara berkala

\section{Deskripsi pengaplikasian metode dengan kegiatan dilapangan}

Pelaksanaan pengabdian dilakukan melalui beberapa tahapan diantaranya : (1) tahap persiapan dan perencanaan, yaitu dosen membagi mahasiswa menjadi beberapa kelompok untuk mengobservasi mengenai kondisi lapangan dan mengidentifikasi masalah yang terjadi, mencari tahu potensi desa dan berbagai permasalahan yang dihadapi.(2) pada tahap pelaksanaan kegiatan pengabdian, pendampingan yang akan di lakukan berupa control terhadap strategi pelaksanaan event yang sudah direncanakan. Memonitor setiap kegiatan berlangsung dengan cara terjun ke lapangan langsung selama beberapa kali sesuai dengan jadwal kunjungan yang telah diatur oleh tim dosen pembimbing lapangan terutama ketika program/event berjalan. (3) Tahap Evaluasi , pada tahap evaluasi tim berupaya selalu megevaluasi kegiatan melalui tanya jawab dengan mahasiswa KKN dan dosen pembimbing lapangan kemudian berdiskusi secara langsung serta mencari solusi bersama ketika terjadi masalah.

Langkah 1 : DPL membagi tim menjadi beberapa kelompok sebagai uapay mempermudah dalam mengobservasi mencari potensi desa dan mengidentifikasi masalah
Langkah 2 : Setelah didapat data mengenai potensi desa, maka dpl mengubah tim menjadi kelompok yang lebih kecil, serta berupaya memfokuskan kegiatan pengabdian pada dua hal, diantaranya peningkatan potensi desa melalui budi daya jamur serta upaya merangsang potensi anak usia din melalui lomba mewarnai di desa Mayang
Langkah 5 ; Palaksanaan kegiatan pameran potensi desa se kecamatan Mayang. Dalam hal ini desa mayang memamerkan potensi budu daya jamur yang sdh berupa produk, yaitu "Jamali" atau kepanjangan dari Jamur Asli Mayang

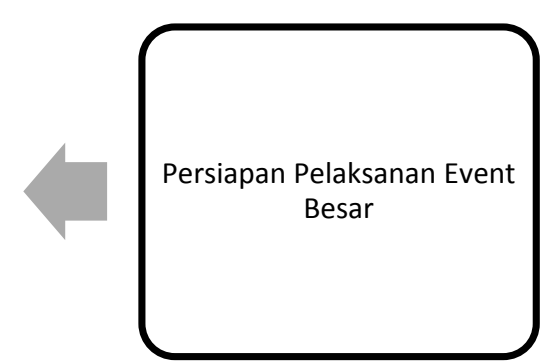

Langkah 4: Setelah di tentukan jadwal maka, khalayak mengikuti kegiatan tersebut. Pada penyuluhan budu daya jamur, khalayak secara

langsung dapat berdiskusi dan mempraktekan langsung kegiatan budi daya jamur. Sedangkan pada upaya peningkatan potensi anak usia dini maka diadakan lomba mewarnai dikantor desa Mayang. 


\section{Metode yang digunakan dalam mengembangkan potensi Jamur:}

Pada latar belakang masalah pengembangan potensi jamur, terlihat bahwa kendala yang ada adalah dimulai proses awal memulai budi daya jamur. Untuk itu maka eetode yang digunakan dalam mengembangkan potensi jamur adalah dengan menggunakan metode penyuluhan yang berisi tentang awal proses pembuatan budidaya jamur, dan menggunakan metode demonstrasi, yaitu dengan memperagakan langsung bagaimana mengembangkan budi daya jamur.

\section{Metode yang digunakan dalam upaya penguatan pendidikan}

Ada berbagai macam upaya penguatan pendidikan pada anak, yaitu dengan mengajar, memberikan pelajaran ekstra atau dengan berkompetisi. Yang terpenting adalah, dalam pembelajaran anak usia dini ada asasyang perlu dikembangkan dalam mengembangkan potensi kemanusiaan pada anak. Sejalan dengan Nurani:2013 bahwa pembelajaran pada anak usia dini hendaknya memperhatikan sejumlah asas diantaranya asas perbedaan individu, asas kekonkretan, asas apersepsi, asas motivasi, asas motivasi, asas kemandirian, asas keterpaduan, asas kerjasama dan asas belajar sepanjang hayat.

Dari beberapa pembelajaran untuk anak usia dini, lomba mewarnai menjadi pilihan untuk merangsang perkembangan anak. Manfaat lomba mewarnai bagi anak diantaranya: (1) membantu mengembangkan potensi anak, (2) melatih keterampilan motoric halus anak, (3) memupuk rasa percaya diri dan mandiri, (4) belajar mengambil keputusan. Untuk itu metode yang digunakan dalam upaya penguatan pendidikan anak adalah melalui metode berkompetisi.

\section{Indikator ketercapaian tujuan pengabdian}

Indikator ketercapaian tujuan pengabdian adalah: (1) pemahaman kesadaran masyarakat mengenai pentingnya penguatan potensi desa. Hal ini ditunjukkan dengan peran aktif masyarakat yang terlibat dalam kegiatan Kuliah Kerja Nyata dan kegiatan Pengabdian Pada Masyarakat. (2) Menghasilkan produk baru sebagai wujud keberhasilan dalam upaya pemberdayaan masyarakat desa, (3) Pelaksanaan event yang berjalan lancar. Event yang dimaksud adalah upaya memamerkan potensi desa agar dikenal oleh masyarakat yang lebih luas serta mendapat perhatian dari dinas perindustrian dan perdagangan. Event yang kedua adalah pelaksanaan lomba mewarnai Anak Usia Dini di Balai Desa Mayang

\section{PEMBAHASAN}

\section{Kegiatan Pendampingan Budi Daya Jamur Tiram yang dilakukan di desa Mayang}

Karena potensi pertanian yang dikembangkan masyarakat desa mayang adalah budidaya jamur, maka kegiatan pengabdian yang dilakukan didesa mayang diantaranya: (1) Pelatihan budidaya jamur, (2) Pengolahan Jamur, (3) Pemasaran Jamur. Kegiatan 
Sosialisasi Pelatihan Budidaya Jamur Tiram dilakukan pada hari Selasa, tanggal 10 April 2018 , bertempat didusun Klayu pada pukul : 10.00 - 17.00 WIB. Metode yang digunakan dalam Sosialisasi Pelatihan Budidaya Jamur Tiram adalah metode penyuluhan dan demonstrasi. Metode ini dilakukan dengan cara menyampaikan materi mengenai Pelatihan Budidaya Jamur Tiram. Materi disampaikan oleh Bapak David yang sudah berkompeten dibidang jamur. Dimana pelaksanaan kegiatan sosialisasi budidaya jamur tiram antara lain: Memberikan teori tentang budidaya jamur tiram, Memberikan prosedur tentang pencampuran komposisi media jamur (baglog) sampai proses penanaman bibit jamur tiram secara benar. Materi dilakukan langsung secara detail dengan membuka sesi Tanya jawab langsung oleh nara sumber. Pemateri juga mempraktikkan lagsung mengenai awal proses pencampuran bahan dasar sampai pada pembibitan.

Selain menyampaikan mengenai proses budi daya jamur, bapak david selaku nara sumber juga memberikan penguatan konsep mengenai pentingnya budidaya jamur dalam meningkatkan perekonomian. Hal ini dilakukan untuk memberitahukan kepada masyarakat desa Mayang agar khalayak tidak merasa putus asa dan tetap bersemangat dalam melakukan budi daya jamur. Kegiatan ini dilaksanakan di kediaman Bapak H.Latif dusun Klayu. Sosialisasi Budidaya Jamur Tiram ini di hadiri oleh masyarakat desa Mayang berjumlah 25 orang. Dengan adaya Sosialisasi Budidaya Jamur Tiram ini masyarakat sangat antusias.

Metode pelaksanaan kegiatan pengabdian ini dilakukan melalui beberapa tahapan, menurut Murdjito (2012): diantaranya: (1) Analisa Situasi Masyarakat yang dilakukan melalui dua tahapan yakni menentukan khalayak sasaran dan menentukan permasalahan yang akan dianalisis, kemudian mencari pihak terkait yaitu orang - orang yang berhubungan dengan masalah yang dihadapi yang kemudian dijadikan sebagai informan. (2) Identifikasi masalah, hasil dari kerja analisis yang mencakup sasaran dan bidang permasalahan tadi adalah dapat ditemukannya dan dirumuskan masalah. (3) Menentukan tujuan kerja secara spesifik. Dalam tahap ini harus ditentukan "kondisi baru" mana yang ingin dihasilkan melalui kegiatan pengabdian. Dengan kata lain menemukan perubahan baru yang diinginkan. (4) Setelah itu kemudian dicari solusi sebagai upaya menangani masalah yang terjadi/ rencana pemecahan masalah yangterdiri darai tahapan mencari alternative pemecahan masalah kemudian memilih salah satu alternative terbaik. (5) Pendekatan Sosial, yaitu pendekatan terhadap masyarakat sasaran. Masyarakat merupakan subyek dan bukan merupakan obyek, untuk itu masyarakat harus sebanyak mungkin dilibatkan. Membangun kesadaran masayarakat akan masalah yang dihadapi dan mencari solusinya. (6) Tahap Pelaksanaan, pada tahap ini meliputi: penetapan bagaimana kegiatan akan dilakukan, penetapan waktu pelaksanaan, penetapan tempat pelaksanaan kegiatan dan penetapan orang yang terlibat dalam kegiatan. (7) Evaluasi hasil kegiatan, pada tahap ini sebisa mungkin menghasilkan bentuk pertanggung jawaban dari segala hal yang dilakukan sebelumnya 
Setelah melalui beberapa tahapan mengenai budi daya jamur. Namun kegiatan tidak berhenti sampai disini. Masih ada tahapan marketing yang akan dilakukan, diantaranya adalah mengolah jamur menjadi jamur krispy. Jamur ini diolah dengan cara dimasak yaitu dengan digoreng lalu diberi bumbu dengan berbagai rasa kemudia dikemas serta diberi nama Jamali yang memiliki kepanjangan Jamur Mayang Asli. Dalam upaya memberdayakan masyarakat desa dalam hal budi daya jamur, ada beberapa factor pendorong diantaranya: (1) Adanya kerja sama yang baik dengan salah satu pengusaha jamur di jember bapak David Barokah Jamur Mangli Jember, (2) Antusias dari masyarakat dusun klayu dalam mengikuti pelatihan budidaya jamur tiram, (3) Adanya salah satu warga dusun klayu yang merintis usaha jamur tiram sehingga mendorong penuh dalam pelaksanaan pelatihan budidaya jamur tiram. Selain itu ada pula yang menjadi factor penghambat yaitu keterlambatan peserta pelatihan budidaya jamur tiram sehingga waktu yang digunakan sedikit mundur dikarenakan peserta pelatihan ada sebagian yang masih bekerja.

Deskrispsi metode dalam pelaksanaan kegiatan pengabdian ini adalah (1) analisa situasi masyarakat dilakukan dalam dua tahapan, yang pertama khalayak sasaran adalah masyarakat desa Mayang. Masalah yang akan dianalisis adalah bagaimana mengoptimalkan potensi desa mayang sebagai upaya peningkatan perekonomian dan merangsang peningkatan kualitas pendidikan anak usia dini. Pihak- pihak terkait yang terlibat dan dijadikan informan dalam kegiatan ini adalah bapak kepala desa, bapak kepala dusun, masyarakat desa mayang. (2) Identifikasi masalah, hasil dari kerja analisis yang mencakup sasaran dan bidang permasalahan sudah dirumuskan dalam perumusan masalah yang terdapat pada bagian atas pada halaman dua. (3) Tujuan kerja secara spesifik dalam kegiatan pengabdian ini adalah setelah memberdayakan masyarakat desa mayang melalui budidaya jamur serta upaya merangsang potensi anak usia dini melalui kegiatan lomba mewarnai, maka akan diadakan pameran potensi desa mayang terkait jamur. Dalam tahap ini "kondisi baru" mana yang dihasilkan melalui kegiatan pengabdian budidaya jamur adalah menghasilkan produk jamur krispy “Jamali”. Dengan adanya "Jamali "ini, maka akan dipamerkan atau dikenalkan pada masyarakat luas. Sedangkan pada upaya peningkatan potensi anak melalui kegiatan lomba mewarnai akan diadakan lomba mewarnai (4) Solusi yang diambil sebagai upaya menangani masalah ini adalah dengan melakukan tahapan tahapan diantaranya: pengenalan dan pendekatan pada masyarakat, mengobservasi budidaya jamur sebelumnya yang pernah gagal, mengevaluasi beberapa kesalahan, melakukan penyuluhan budi daya Jamur. Sedangkan dalam kegiatan lomba mewarnai diadakan sehari dengan suasana yang dikondisikan dan disesuaikan dengan usia anak usia dini (5) Pendekatan Sosial, yang dilakukan yaitu pendekatan terhadap masyarakat sasaran yaitu msyarakat desa Mayang di Dusun Klayu sebagai petani Jamur. Sedangkan pada kegiatan lomba mewarnai ditujukan untuk TK di desa Mayang (6) Tahap Evaluasi hasil kegiatan adalah mengevaluasi kembali pembibitan jamur karena pada penyuluhan kali ini menggunakan tekhnik penanaman yang berbeda, 
serta menghasilkan produk yang belum ada sebelumnya. Produk tersebut berupa jamur crispy Jamali. Jamali merupakan kepanjangan dari Jamur asli mayang. Untuk meningkatkan perekonomian desa Mayang. Ada beberapa hal yang dilakukan yang diharapkan mampu mendongkrak perekonomian desa mayang. Diantaranya : Meningkagtkan kualitas budi daya jamur mulai dari pengawasan dari awal hingga pemrosesan marketing. Dengan adanya pengawasan yang maksimal maka diharapkan produk yang dihasilkan akan lebih baik sehingga memiliki nilai jual yang bagus.

Salah satu upaya dalam memberikan perubahan ke arah yang lebih baik dalam hal pemasaran produk desa adalah dengan dilakukannya pameran potensi desa. Event yang diadakan di desa Mayang tepatnya dikantor Kecamatan Mayang bertujuan untuk mengenalkan potensi - potensi desa se Kecamatan Mayang. Beberapa produk yang dipamerkan dari desa Mayang adalah adalah jamur crispy Jamali dan ladrang snack makanan desa asli buatan warga Mayang. Selain itu ada juga potensi dari sumber daya manusianya, yaitu berupa pencak silat yang dipamerkan dilapangan kecamatan Mayang

Dalam pameran potensi desa yang diadakan tersebut, selain bertujuan memamerkan potensi desa Mayang, tujuan lainnya adalah menjual/memasarkan produk jamur crispy ini ke masyarakat sekitar, dengan harapan akan ada perhatian pula pada masyarakat yang lebih luas melalui dinas perindustrian dan perdagangan dan dinas pariwisata serta dinas lain terkait dengan pengembangan potensi desa.

\section{Kegiatan Pendampingan dalam upaya penguatan di bidang pendidikan pada Anak Usia Dini}

Ada beberapa hal yang dilakukan untuk meningkatkan kualitas pendidikan di desa Mayang, diantaranya: mengajar, memberikan pelajaran Tambahan/ Les serta mengadakan lomba mewarnai untuk anak usia dini. Salah satu upaya yang dilakukan dalam meningkatkan kualitas pendidikan anak usia dini di desa Mayang adalah dengan mengadalan lomba mewarnai. Lomba mewarnai memiliki manfaat yang baik diantaranya membangun rasa percaya diri dan keberanian anak, melatih kemandirian anak dan membangun cara berpikir anak, membantu anak dalam mengambil keputusannya sendiri dalam memecahkan masalah saat mengikuti lomba, mengajarkan anak untuk lebih kreatif, membiasakan anak berjuang dalam hal positif, memicu sel otak kanan yang akan bermanfaat untuk kecerdasan berfikir dan bersikap.

Pelaksanaan lomba mewarnai tingkat TK/RA, KB (PAUD) dalam rangka Memperingati Hari Kartini Serta upaya Meningkatkan Potensi dan Kreativitas Anak Usia Dini di Desa Mayang, Kecamatan Mayang dilaksanakan pada tanggal 19 april 2018. Kegiatan yang diselenggarakan bisa berjalan dengan lancar. Lomba mewarnai ini di sambut antusias oleh lembaga TK/RA, KB Se-Desa Mayang, mereka mengirimkan delegasinya untuk mengikuti lomba mewarnai. Adapun jumlah peserta yang mengikuti lomba mewarnai yaitu 35 orang. 
Kegiatan pendampingan pada pelaksanaan lomba mewarnai yang dilakukan dosen pebimbing lapangan adalah dengan menjadi juri lomba mewarnai. Pada pelaksanaan lomba mewarnai, ada kegiatan Tanya jawab spontan yang dilakukan oleh juri selaku dosen pembimbing lapangan. Tanya jawab tersebut mengenai seputar kegiatan pelibatan orang tua dan anak yang dilakukan oleh ibu dan anak di desa mayang. Antusias peserta lomba dan pendamping lomba sangat tinggi. Hal tersebut ditunjukkan dengan keterlibatan mereka saat mengikuti lomba hingga akhir acara serta keterlibatan mereka menjawab pertanyaan juri selaku dosen pebimbing lapangan. Antusias mereka juga ditunjukkan dengan spontanitas ibu ibu dan anak anak dalam mengisi acara di sela-sela penghitungan nilai. Adapun hasil penillaian menujukkan : Juara 1 : TK Kemala bhayangkari, Juara 2 : TK Al- Islah, Juara 3 : TK Kemala Bhayangkari

\section{KESIMPULAN DAN SARAN Kesimpulan}

Kegiatan pengabdian yang dilakukan di desa Mayang adalah berupa pendampingan Kuliah Kerja Nyata/KKN. Pendampingan ini merupakan pendampingan pada mahasiswa KKN IKIP PGRI Jember. Hasil yang didapat adalah terbaginya mahasiswa KKN dengan memfokuskan pada dua hal penguatan yaitu penguatan pendidikan dan penguatan pada sector ekonomi. Dalam upaya penguatan di bidang pendidikan kegiatan yang dilakukan adalah lomba mewarnai pada Anak Usia Dini. Sedangkan pendampingan pada pengembangan potensi yang dilakukan di desa Mayang adalah pendampingan budi daya jamur.

\section{Saran}

Upaya meningkatkan potensi desa baik sumberdaya manusianya maupun sumber daya alamnya memerlukan campur tangan pemerintah dan pihak -pihak terkait. Selama ini perhatian terhadap perkembangan desa mayang sangat kurang. Sehingga masyarakat kehilangan spirit dalam menggali diri dan mengembangkan potensi diri. Untuk itu alangkah bijak, jika pemerintah lebih memperhatikan juga apapun dan bagaimanapun kondisi desa agar lebih berkembang dengan menggali potensi yang ada di desa. Seperti pada upaya budi daya jamur, agar tidak hanya berhenti pada pengawasan produk budidaya jamur tiram, tetapi juga perlu adanya strategi marketing yang bagus, yaitu dengan mengolah hasil panen jamur tiram menjadi olahan yang siap makan dengan membuat jamur crispy yang dikemas secara rapi dan baik yang nantinya akan dipasarkan melalui toko - toko makanan dan bisa menjadi salah satu jajanan khas dari desa mayang kecamatan mayang kabupaten Jember. 


\section{DAFTAR PUSTAKA}

Nurani Yuliani. 2013. Konsep Dasar Pendidikan Anak Usia Dini. Jakarta: Indeks

Murdjito. 2012. Metoda Pengabdian Kepada Masyarakat. https://www.slideshare.net>fitri Riyanto 